\begin{tabular}{|c|c|c|c|c|}
\hline $\begin{array}{c}\text { Focus: Jurnal } \\
\text { Pekerjaan Sosial }\end{array}$ & ISSN: $2620-3367$ & Vol. 2 No: 2 & Hal: $178-186$ & Desember 2019 \\
\hline
\end{tabular}

\title{
MEMAHAMI PERKEMBANGAN ANAK GENERASI ALFA DI ERA INDUSTRI 4.0
}

\author{
Ishak Fadlurrohim, Asmar Husein, Liya Yulia, Hery Wibowo, Santoso Tri Raharjo \\ ${ }^{1}$ Program Magister Kesejahteraan Sosial Fakultas Ilmu Sosial dan Ilmu Politik, Universitas Padjadjaran, \\ Jl. Bukit Dago Utara No.25 Bandung 40135 \\ Program Pascasarjana FISIP Unpad
}

\begin{abstract}
ABSTRAK
Industri 4.0 diprediksi memiliki potensi manfaat yang besar dalam perkembangan yang pesat dalam pemanfaatan teknologi digital. Hal tersebut berdampak positif terhadap perkembangan ekonomi. Namun terdapat tantangan yang harus dihadapi dengan munculnya resistensi terhadap perubahan demografi dan aspek sosial, ketidakstabilan kondisi politik, keterbatasan sumber daya, resiko bencana alam dan tuntutan penerapan teknologi yang ramah lingkungan. Generasi alpha merupakan anak - anak yang dilahirkan oleh generasi milenial. Istilah ini dikemukakan oleh mark Mc Crindle melalui tulisan di majalah Business Insider (Christina Sterbenz, 2015). Generasi alpha (2011 - 2025) generasi yang paling akrab dengan teknologi digital dan generasi yang diklaim paling cerdas dibandingkan generasi generasi sebelumnya. Sebanyak 2,5 juta anak generasi alpha lahir di dunia setiap minggunya. Gen A merupakan generasi paling akrab dengan internet sepanjang masa. Mc Crindler juga memprediksi bahwa generasi Alpha tidak lepas dari gadget, kurang bersosialisasi, kurang daya kreativitas dan bersikap individualis. Generasi alpha menginginkan hal-hal yang instan dan kurang menghargai proses. Keasyikan mereka dengan gadget membuat mereka teralienasi secara sosial. Artikel ini bertujuan untuk memahami perkembangan anak generasi alfa di era industri 4.0. Metode yang digunakan dalam penelitian ini adalah metode studi pustaka Metode yang digunakan dalam artikel memahami perkembangan anak generasi alfa di era industri 4.0 adalah menggunakan pendekatan studi kepustakaan dimana mengumpulkan data dengan mengadakan studi penelaahan terhadap buku buku, literatur, catatan dan laporan- laporan yang ada hubungan nya dengan masalah yang dipecahkan (Nazir, 2015). Sumber yang di peroleh berkaitan dengan perkembangan anak generasi alfa di era industri 4.0. Artikel ini menemukan bahwa merubah cara pandang dan pola hidup masyarakat yang semula konvensional menjadi inkonvensional. Terlebih pertumbuhan teknologi, mau tidak mau masyarakat dituntut untuk berevolusi. Berdasarkan seluruh aspek kehidupan, peran keluarga yang paling penting dalam proses tumbuh kembang anak. Maka peran keluarga yang sudah pasti terdiri dari generasi $Y$ dan $Z$ yang cenderung sebagai pengambil keputusan, sementara generasi veteran dan $X$ berperan sebagai konselor dan pendamping sehingga menghasilkan kolaborasi antar generasi menghasilkan new brainstorming terhadap generasi alpha. Mc Crindler juga memprediksi bahwa generasi Alpha tidak lepas dari gadget, kurang bersosialisasi, kurang daya kreativitas dan bersikap individualis.
\end{abstract}

\section{Kata Kunci : Perkembangan Anak ; Generasi Alfa ; Era Industri 4.0 ;}

\section{ABSTRACT}

Periode industry 4.0 predicted has the potential benefits of rapid expansion in the use of digital technology. This is a positive impact on economic development. Yet there was challenges to be faced with the emergence of resistance to demographic change and social aspects, instability political conditions, the limited means, the risk of natural disasters and demands application of technology environmentally friendly. The alpha is a children born of milenial generation. The term is presented by mark Mc Crindle through the magazine business insider (christina sterbenz, 2015). The alpha ( 2011 - 2025) the most familiar with digital technology and the generation claimed the smartest than any previous generation.Some 2,5 million children generation alpha born in the world every week. Genes A is the most familiar with the internet all time. Mc crindler is predicted that generation alpha can be gadgets, not socialize, lacking power creativity and be individualist. The alpha want hal-hal instant and less appreciate the process. Preoccupation them with gadgets make them teralienasi socially. This article is intended to understand child development alpha 


\begin{tabular}{|c|c|c|c|c|}
\hline $\begin{array}{c}\text { Focus: Jurnal } \\
\text { Pekerjaan Sosial }\end{array}$ & ISSN: 2620-3367 & Vol. 2 No: 2 & Hal: $178-186$ & Desember 2019 \\
\hline
\end{tabular}

generation of 4.0 industry. Methods used in research is a method of the literature study methods used in article understand child development generation alfa in the industry 4.0 is used the literature study where collect data with a study on the books, Literature, notes and reports of a connection report problems solved (Nazir, 2015). Sources in get relating to child development 4.0 alpha in the industrial era. This article found that changing the way of view and lifestyle to conventional inkonvensional into the community. The technology growth, inevitably the community are required to have evolved. Based on all aspect of life, the role of family the most important thing for the process of growing children developed. So the role of family that is certain consisting of generation $y$ and $z$ who tend as decision-making, while generation veteran and $x$ act as counselor and flanking so as to produce collaboration between produce new go brainstorm generation to generation alpha. Mc crindler also predicts that generation alpha can not be separated from gadgets, less sociable, lacking power creativity and be individualist.

\section{Keywords; Child Development ; Alfa Generation ; Industrial 4.0 Era ;}

\section{PENDAHULUAN}

Istilah industri 4.0 lahir dari ide revolusi industri ke empat. European Parlimentary Research Service dalam Davies (2015) menyampaikan bahwa revolusi industri terjadi di inggris pada tahun 1784 dimana penemuan mesin uap dan mekanisasi menggantikan pekerjaan manusia. revolusi yang kedua terjadi pada akhir abad ke-19 di mana mesin-mesin produksi secara masal. Penggunaan teknologi komputer untuk otomatisasi manufaktur mulai tahun 1970 menjadi tanda revolusi industri ketiga. Saat ini, perkembangan yang pesat dari teknologi sensor, interkoneksi dan analisis data memunculkan gagasan untuk mengintegrasikan seluruh teknologi tersebut ke dalam berbagai bidang industri. Gagasan inilah yang diprediksi akan menjadi revolusi industri yang berikutnya. Angka empat pada istilah industri 4.0 merujuk pada revolusi yang ke empat. Industri 4.0 merupakan fenomena yang unik jika dibandingkan dengan tiga revolusi industri yang mendahuluinya. Industri 4.0 diumumkan secara apriori karena peristiwa nyata yang belum terjadi dan masih dalam bentuk gagasan (Drath dan Hotch, 2014).

Industri 4.0 diprediksi memiliki potensi manfaat yang besar dalam perkembangan yang pesat dalam pemanfaatan teknologi digital. Hal tersebut berdampak positif terhadap perkembangan ekonomi. Namun terdapat tantangan yang harus dihadapi. Darth dan horch (2014) berpendapat bahwa tantangan yang dihadapi oleh suatu negara ketika menerapkan industri 4.0 adalah munculnya resistensi terhadap perubahan demografi dan aspek sosial, ketidakstabilan kondisi politik, keterbatasan sumber daya, resiko bencana alam dan tuntutan penerapan teknologi yang ramah lingkungan. Menurut Jian Qin dkk (2016), secara umum ada lima tantangan besar yang akan dihadapi yaitu aspek pengetahuan, teknologi, ekonomi, sosial dan politik.

Perkembangan teknologi yang pesat tentunya mempengaruhi berbagai bidang yang ada seperti sosial yang berdampak kepada perkembangan interaksi sosial antar individu maupun masyarakat. Sehingga memunculkan generasi yang lebih modern dalam menghadapi era teknologi saat ini. Hal ini dapat terlihat dari setengah manusia di muka bumi telah menggunakan internet hingga tahun 2018. Apabila jumlah populasi manusia di dunia 8 milyar orang, setidaknya manusia berinteraksi dengan internet (wearesocial.com). dari jumlah tersebut, sekitar 132 juta merupakan penduduk indonesia. Itu artinya separuh penduduk indonesia menggunakan internet dari total populasi sekitar 264 juta. (Global digital report tahun 2018) hal tersebut menakjubkan banyak orang. Beberapa variabel terkait penggunaan internet di indonesia juga menarik perhatian. Dari 132 juta penduduk indonesia pengguna internet, $60 \%$ menggunakan ponsel cerdas untuk menggunakan internet. Fakta ini dikonfirmasi dengan fakta di masyarakat. Selain itu, menurut international data corporation (IDC), indonesia masih menjadi pangsa pasar besar bagi para vendor smartphone, seperti samsung $(31,8 \%)$, oppo $(22,9 \%)$, advan $(7,7 \%)$, Asus $(6,5 \%)$ dan vivo $(6,0 \%)$ (id.priceprice.com).

Kedua dari sisi durasi menggunakan internet, indonesia menempati peringkat keempat dunia dengan durasi rata-rata menggunakan internet selama 8 jam 51 menit setiap harinya. Dari jumlah waktu tersebut, sebagian besar digunakan untuk bersosialisasi di dunia maya. Fakta ini dikonfirmasi dengan jumlah pengguna social media mencapai $49 \%$ popilasi pengguna internet. Itu artinya hampir 


\begin{tabular}{|c|c|c|c|c|}
\hline $\begin{array}{c}\text { Focus: Jurnal } \\
\text { Pekerjaan Sosial }\end{array}$ & ISSN: $2620-3367$ & Vol. 2 No: 2 & Hal: $179-186$ & Desember 2019 \\
\hline
\end{tabular}

separuh pengguna internet di indonesia telah memiliki social media. Selain itu, indonesia merupakan negara ketiga terbesar pengguna social media dengan tingkat pertumbuhan mencapai $23 \%$ atau 24 juta pengguna dalam satu tahun terakhir dan facebook merupakan platform social media yang paling banyak digunakan untuk sosialisasi selain instagram. Ketiga dari sisi durasi waktu yang digunakan untuk berinteraksi di social media. Indonesia menempati salah satu peringkat tertinggi di dunia dengan lama durasi menggunakan social media sebesar 3 jam 23 menit (30\%) digunakan untuk social media.

Menurut Hurlock (1993:37) dalam bukunya yang berjudul Child Development, perkembangan anak dibagi menjadi 5 periode yaitu (a) periode pra lahir yang dimulai dari saat pembuahan sampai lahir. Pada periode ini terjadi perkembangan fisiologis yang sangat cepat yaitu pertumbuhan seluruh tubuh secara utuh (b) Periode neonatus adalah masa bayi yang baru lahir. Masa ini terhitung mulai 0 sampai dengan 14 hari. Pada periode ini bayi mengadakan adaptasi terhadap lingkungan yang sama sekali baru untuk bayi tersebut yaitu lingkungan di luar rahim ibu (c) Masa bayi adalah masa bayi berumur 2 minggu sampai 2 tahun. Pada masa ini bayi belajar mengendalikan ototnya sendiri sampai bayi tersebut mempunyai keinginan untuk mandiri (d) Masa kanak-kanak terdiri dari 2 bagian yaitu masa kanakkanak dini dan akhir masa kanak-kanak. Masa kanak-kanak dini adalah masa anak berusia 2 sampai 6 tahun, masa ini disebut juga masa pra sekolah yaitu masa anak menyesuaikan diri secara sosial. Akhir masa kanak-kanak adalah anak usia 6 sampai 13 tahun, biasa disebut sebagai usia sekolah (e) Masa puber adalah masa anak berusia 11 sampai 16 tahun. Masa ini termasuk periode yang tumpang tindih karena merupakan 2 tahun masa kanak-kanak akhir dan 2 tahun masa awal remaja. Secara fisik tubuh anak pada periode ini berubah menjadi tubuh orang dewasa.

Ada beberapa karakteristik pertumbuhan dan perkembangan psiko - fisik anak menurut Kartini Kartono dalam buku Psikologi Anak, yaitu: (a) Umur 1 - 6 tahun : kecakapan moral berkembang, aktivitas dan ruang gerak mulai aktif, permainan bersifat individu, sudah mengerti ruang dan waktu, bersifat spontan dan ingin tahu, warna mempunyai pengaruh terhadap anak, suka mendengarkan dongeng (b) Umur $6-8$ tahun : koordinasi psiko motorik semakin berkembang, permainan sifatnya berkelompok, tidak terlalu tergantung pada orang tua, kontak dengan lingkungan luar semakin matang, menyadari kehadiran alam disekelilingnya, bentuk lebih berpengaruh daripada warna, rasa tanggung jawab mulai tumbuh, puncak kesenangan bermain adalah pada umur 8 tahun (c) Umur $8-12$ tahun : koordinasi psiko motorik semakin baik, permainan berkelompok, teratur, disiplin, kegiatan bermain merupakan kegiatan setelah belajar, menunjukkan minat pada hal-hal tertentu, sifat ingin tahu, coba-coba, menyelidiki, aktif, dapat memisahkan persepsi dengan tindakan yang menggunakan logika, dapat memahami peraturan.

Pada sisi lain peran serta keluarga, terutama ayah dan ibu dalam memberikan pendidikan sangat penting. Apalagi, mengingat tantangan yang sangat besar mengacu pada 21st Century Partnership Learning Framework, bahwa pendidikan abad 21 harus mampu menghasilkan outcomes yang memiliki beberapa keterampilan utama, yaitu (1) learning and innovation skills yang mencakup : creativity and innovation, critical thinking and problem solving, communication and collaboration (2) information, media and technologi skills yang mencakup information literacy, media literacy and ICT (information, comunication and technology) literacy dan (3) life and career skills yang mencakup : flexibility and adaptability, initiative and self direction, social and cross cultural skills, productivity and accountability dan leadership and responsibility.

Generasi alpha merupakan anak - anak yang dilahirkan oleh generasi milenial. Istilah ini dikemukakan oleh mark Mc Crindle melalui tulisan di majalah Business Insider (Christina Sterbenz, 2015). Generasi alpha (2011 - 2025) generasi yang paling akrab dengan teknologi digital dan generasi yang diklaim paling cerdas dibandingkan generasi generasi sebelumnya. Sebanyak 2,5 juta anak generasi alpha lahir di dunia setiap minggunya. Gen A merupakan generasi paling akrab dengan internet sepanjang masa. Mc Crindler juga memprediksi bahwa generasi Alpha tidak lepas dari gadget, kurang bersosialisasi, kurang daya kreativitas dan bersikap individualis. Generasi alpha menginginkan hal-hal yang instan dan kurang menghargai proses. Keasyikan mereka dengan gadget membuat mereka teralienasi secara sosial.

Perkembangan anak (generasi alpha) di era 4.0. hal ini tentunya merubah cara pandang dan pola hidup masyarakat yang semula konvensional menjadi inkonvensional. Terlebih pertumbuhan teknologi, mau tidak mau masyarakat dituntut untuk berevolusi. Berdasarkan seluruh aspek kehidupan, 


\begin{tabular}{|c|c|c|c|c|}
\hline $\begin{array}{c}\text { Focus: Jurnal } \\
\text { Pekerjaan Sosial }\end{array}$ & ISSN: $2620-3367$ & Vol. 2 No: 2 & Hal: $178-186$ & Desember 2019 \\
\hline
\end{tabular}

peran keluarga yang paling penting dalam proses tumbuh kembang anak. Jika yang di bicarakan adalah generasi alpha, maka peran keluarga yang sudah pasti terdiri dari generasi $Y$ dan $Z$ yang cenderung sebagai pengambil keputusan, sementara generasi veteran dan $\mathrm{X}$ berperan sebagai konselor dan pendamping sehingga menghasilkan kolaborasi antar generasi menghasilkan new brainstorming terhadap generasi alpha. Terdapat 2,5 juta gen alfa lahir/ minggu di dunia. Generasi alfa akan menjadi generasi yang paling terdidik karena kesempatan sekolah yang lebih banyak di era sekarang ; akrab dengan teknologi ; paling sejahtera ; punya jarak umur paling jauh dengan generasi sebelumnya (mengalahkan jarak anatara baby boomer - generasi $X)$. Serta hal yang mempengaruhi generasi alfa adalah (1) ledakan kelahiran pada 2020 yang menyebabkan india jadi negeri paling banyak penduduknya pada 2028 menggantikan china. (2) alfa akan jadi generasi yang sangat bergantung pada teknologi, melebihi milenial dan gen $Z$. (bussines insider \& McCrindle dalam tirto id).

Hal yang dapat dilihat dalam proses perkembangan anak generasi alpha terlihat dalam 8 jenis tahap perkembangan psikososial Erikson meliputi (a. Trust and Mistrust (0-1) (b. Otonomi and ragu-ragu (1-3) (c. inisiatif dan kesalahan (4-5) (d. kerajinan dan inferioritas (6-12) (e. identitas dan kekacauan identitas (12-18) (f. keintiman dan isolasi 18/20-30 (g. generatif dan stagnasi (20-55) (h. integritas dan keputusasaan (lansia). Pada artikel ini lebih berfokus kepada perkembangan anak, maka hanya melihat 5 tahapan perkembang psikososial. Selanjut nya dapat melihat bentuk perkembangan generasi alpha dilihat dari teori jean piaget yang didalamnya berfokus pada kognitif manusia. termasuk didalamnya perkembangan kognitif manusia sejak lahir hingga dewasa diantaranya (a. Masa prenatal (b. Masa infancy (c. Masa early childhood (d. Masa Late childhood (e. Masa remaja (f. Dewasa dan tua. Selain itu terdapat sistem ekologi perkembangan yang dapat menunjukkan pola perkembangan anak generasi alpha di era 4.0. hal ini dilihat melalui teori ekologi perkembangan Urie Brofenbrenner yang berfokus pada konteks sosial yang mempengaruhi perkembangan anak. Teori ini terdiri dari lima sistem lingkungan yang merentang dari interaksi interpersonal sampai ke pengaruh kultural yang lebih luas diantaranya: microsystem, mesosystem, exosystem, macrosystem dan cronosystem. Pada teori ini lebih menekankan pada dua faktor penting yaitu (1) banyak nya anak yang hidup dalam kemiskinan, terutama keluarga yang single parent dan (2) penurunan nilai - nilai.

Maka hal ini lah yang dinilai dapat menggambarkan generasi alpha di era 4.0, dimana terdapat perubahan tahapan perkembangan yang terjadi serta menimbulkan dampak dalam berkurangnya nilai nilai yang dimiliki anak di usia nya baik terhadap keluarga maupun lingkungan masyarakat.

\section{METODE}

Metode yang digunakan dalam artikel memahami perkembangan anak generasi alfa di era industri 4.0 adalah menggunakan pendekatan studi kepustakaan dimana mengumpulkan data dengan mengadakan studi penelaahan terhadap buku buku, literatur, catatan dan laporan- laporan yang ada hubungan nya dengan masalah yang dipecahkan (Nazir, 2015). Sumber yang di peroleh berkaitan dengan perkembangan anak generasi alfa di era industri 4.0.

\section{HASIL DAN PEMBAHASAN}

Profesor Sri Moertiningsih dalam artikel nya Transisi demografi, bonus demografi dan the widow of opportunity menyebutkan dampak sukses pembangunan kependudukan dan kesehatan adalah perubahan struktur penduduk yang di pengaruhi oleh beberapa hal berikut : Penurunan kelahiran menurunkan proporsi jumlah anak $<15$ tahun ; Penurunan kematian bayi meningkatkan jumlah bayi yang tetap hidup keusia dewasa ; Ledakan peduduk usia kerja ; Age dependency ratio - proporsi penduduk muda terhadap penduduk usia kerja menurun. Perubahan struktur kependudukan dan menurunnya beban ketergantungan memberikan peluang yang disebut bonus demografi atau demographic dividend. Bonus demografi ini seringkali dikaitkan dengan the widow of opportunity atau jendela peluang yang dapat diartikan sebagai munculnya suatu kesempatan yang dapat meningkatkan kesejahteraan masyarakat.

Menurut moetiningsih (2012) the widow of opportunity terjadi tahun 2020 - 2030 dimana dependency ratio (tingkat ketergantungan usia non produktif terhadap usia produktif) mencapai titik terendah. Yaitu 44 per 100 jiwa. Dependency ratio tersebut menigkat lagi tahun 2030 dikarenakan meningkatnya proporsi penduduk lansia. Kejadian ini 


\begin{tabular}{|c|c|c|c|c|}
\hline $\begin{array}{c}\text { Focus: Jurnal } \\
\text { Pekerjaan Sosial }\end{array}$ & ISSN: $2620-3367$ & Vol. 2 No: 2 & Hal: $179-186$ & Desember 2019 \\
\hline
\end{tabular}

menurut moertiningsih hanya terjadi satu kali dalam sejarah suatu penduduk.

Bonus demografi menjadi topik pembahasan yang cukup menarik dan seringkali dikait - kaitkan dengan pertumbuhan ekonomi bangsa indonesia dikarenakan beberapa hal berikut (Moertiningsih, 2012): Suplai tenaga kerja yang besar meningkatkan pendapatan per kapita apabila mendapat kesempatan kerja yang produktif ; Peranan perempuan : jumlah anak sedikit memungkinkan perempuan memasuki pasar kerja, membantu peningkatan pendapatan ; Tabungan masyarakat yang diinvestasikan secara produktif. Modal manusia yang besar apabla ada investasi untuk itu.

The widow of opportunity dapat saja berubah menjadi the door to disaster apabila bangsa indonesia tidak bersiap menghadapi ledakan jumlah angkatan kerja pada tahun 2025, karena ledakan jumlah tenaga kerja yang sebanding dengan jumlah angkatan kerja.

Teori mengenai generasi di angkatan kerja dipopulerkan oleh William Strauss dan Neil Howe yang mengidentifikasi mengenai siklus generasi di sejarah Amerika Serikat. Strauss dan Howe banyak diambil menjadi landasan bagi riset serta penelitian mengenai perilaku generasi, Traditionalist, Baby Boomers, Gen X, Gen Y dan Gen Z.

Traditionalist (kelahiran antara 1920-1945), menurut clark (2009) dan Mc Donald (2008) yang dituliskan kembali oleh mujtaba (2010) adalah generasi yang memiliki nilai - nilai loyalitas, disiplin, menghormati otoritas serta menempatkan tugas (pekerjaan) diatas kesenangan pribadi. Generasi ini tumbuh ditengah perang dunia kedua dan saat ini sudah tidak terlalu banyak yang masih bekerja, jika saat ini organisasi mempertimbangkan untuk menggunakan jasa Traditionalist maka sangat disarankan untuk fokus kepada pendekatan personal serta memberikan penghormatan dikarenakan usia yang cukup senior (Bursch, 2014).

Baby Boomers (kelahiran antara 1946-1964) merupakan nama yang diberikan kepada generasi ini dikarenakan mereka adalah bagian dari baby boom setelah perang dunia kedua. Generasi ini menjadi tumpuan orang tua mereka (generasi traditionalist) yang memiliki harapan besar mengenai hal - hal yang akan mereka capai (Mujtaba, 2010). Seperti Traditionalist, generasi ini memiliki nilai - nilai loyalitas, disiplin serta work ethic yang kuat. Namun kesamaan nilai - nilai tersebut memiliki perbedaan latar belakang. Ketika traditionalist banyak dipengaruhi oleh masa kecil dan bagaimana mereka tumbuh, baby boomers lebih dipengaruhi oleh prestise, kesejahteraan dan jabatan.

Generasi $\boldsymbol{X}$ (kelahiran antara 1965-1976) dikenal juga dengan nama gen Xers. Gen Xers di tempat kerja banyak dipengaruhi oleh persepsi dan pencapaian orang tua mereka (baby boomers) yang bekerja keras untuk mencapai kesejahteraan dan menyekolahkan gen $X$. Gen Xers mulai mempertimbangkan apa yang dinamakan work life balance sebagai dampak mereka menyaksikan cara bekerja dan kompensasi yang diterima oleh Baby Boomers tidaklah membawa kebahagiaan untuk mereka, bahkan salah satu studi dari mujtaba (2010) mengatakan tingkat perceraian yang tinggi dari orangtua gen Xers sangat mempengaruhi cara pandang mereka terhadap kebahagiaan keluarga.

Gen Xers menjadi saksi atas kelahitan internet dan teknologi yang kelak mengubah cara interaksi dalam pekerjaan, sehingga secara teknis GenXers cukup baik sebagai user (Bursch, 2014). Gen Xers cenderung berbeda pendapat terhadap prosedur, kebijakan dan struktur organisasi sehingga dapat dikatakan penghormatan mereka terhadap otoritas sedikit berbeda dengan generasi traditionalist dan baby boomers.

Generasi $\boldsymbol{Y}$ (kelahiran 1977-1998) dikenal juga dengan nama Millenials yang disadur dari istilah pada buku Strauss dan Howe Millenials Rising: The Next Generation. Millenials percaya bahwa pendidikan adalah kunci untuk sukses dan mereka siap untuk menjadi pembelajar seumur hidup (Mujtaba, 2010). Gen $\boldsymbol{Y}$ memiliki tingkat harga diri dan narsisme lebih besar daripada generasi sebelumnya. Hal ii tentu berdampak terhadap ekspektasi besat mereka di tempat kerja (terkait dengan penghargaan serta kondisi kerja) Bursch (2014) mengatakan bahwa Gen Y diidentifikasikan sebagai generasi yang paling beragam (sifat, perilaku dan kultur) dan Gen $Y$ akan sangat mewarnai keragaman di tempat kerja.

Gen $Y$ tumbuh ada dunia yang selalu terhubung selama 24 jam dan 7 hari sehingga informasi bagi generasi $\mathrm{Y}$, informasi adalah hal yang cenderung mudah dan cepat didapatkan. Hal tersebut mempengaruhi cara mereka mencari informasi, memecahkan masalah, hubungan dengan orang lain dan berkomunikasi. Gen $Y$ cenderung berpindah pekerjaan jika merasa ekspektasi mereka terhadap pekerjaan tidak terpenuhi. Hal ini dipengaruhi oleh harga diri dan narsisme mereka yang begitu tinggi.

Karakteristik Gen Y di tempat Kerja Bursch (2014) menuliskan bahwa gen $Y$ adalah generasi 


\begin{tabular}{|c|c|c|c|c|}
\hline $\begin{array}{c}\text { Focus: Jurnal } \\
\text { Pekerjaan Sosial }\end{array}$ & ISSN: $2620-3367$ & Vol. 2 No: 2 & Hal: $178-186$ & Desember 2019 \\
\hline
\end{tabular}

yang paling tinggi tingkat pendidikannya. Gen $Y$ mendambakan pekerjaan dimana mereka turut ambil bagian dalam misi organisasi. Nilai pekerjaan yang lebih berarti dibandingkan dengan mendapatkan uang dalam jumlah besar.

Menurut Fernandez (2012), Generasi Y lebih menghargai waktu luang dibandingkan dengan generasi $X$. Perusahaan terkemuka seperti google, Ebay, KPMG saat ini menawarkan waktu luang tersebut lebih banyak kepada karyawan mereka dengan cara memberi beberapa fasilitas tambahan pada karyawan mereka di tempat bekerja. Gen $Y$ memilih atasan yang memiliki pendekatan secara pendidikan (empiris) serta memberi perhatian terhadap tujuan personal dari Generasi Y. Nilai terhadap atasannya adalah orang yang melatih mereka, bersikap positif, mampu memotivasi, berorientasi terhadap pencapaian. Untuk tetap membuat seorang Gen $Y$ nyaman dan tidak meninggalkan pekerjaan. Perusahaan harus memastikan agar merasa berarti dalam pekerjaan serta mengkomunikasikan kontribusi terhadap misi organisasi. Gen $Y$ juga akan selalu mencari kesempatan untuk terlibat dalam aktifitas filantropis serta relawan (Bursch, 2014). Artinya Gen Y selalu mencari lingkungan yang sempurna dimana mereka dapat mempelajari kemampuan dan pengalaman untuk masa depan mereka selain itu Gen $Y$ membutuhkan iklim kerja yang positif dari rekan kerja mereka (Fernandes, 2012).

Next Generation: (Gen Z) Rothman (2014) memprediksi bahwa pada tahun 2020 generasi Z (kelahiran 1995 - 2010) akan membanjiri pasar dunia kerja. Dalam jurnalnya Rothman menganalogikan gen $\mathrm{Z}$ akan membanjiri pasar dunia kerja seperti layaknya tsunami. Ketika kita ada pada masa usia produktif saat gen $\mathbf{Z}$ memasuki dunia kerja maka kita disarankan mempelajari karakteristik gen Z ini. Menurut Singth (2014), generasi Z dibesarkan oleh generasi $X$ di tengah - tengah tantangan dunia seperti terorisme (peristiwa 9 september di amerika serikat) dan perhatian kepada lingkungan disebarluaskan melalui jaringan sosial mereka. Generasi Z menurut Singht (2014) memiliki sedikit saudara kandung dibandingkan dengan generasi sebelumnya, indikasinya Gen $Z$ juga diprediksi akan lebih memilih jiwa kewirausahaan dibandingkan gen Y. Generasi Z memiliki beberapa perbedaan nyata dengan gen $Y$ dalam beberapa hal : Akses terhadap pengetahuan mengenai sumber daya (internet) yang lebih dibandingkan gen $Y$ pada usia yang sama ; Gen Z yang kebanyakan memiliki orang tua seorang gen $X$ akan mendapatkan lebih banyak tekanan dalam kehidupan mereka, baik dari sisi penapaian akademis maupun dalam berperilaku ; Gen Z memiliki waktu lebih banyak seamasa muda nya untuk mendapatkan semacam mentor yang akan mempengaruhi cara berpikir mereka. Misalkan dengan mudah mereka mempelajari mengenai steve jobs dan membaca nya disaat masih muda.

Beberapa nama lain dari generasi $Z$ adalah Internet Generation (IGen), digital natives, screensters dan zeds. Banyak sumber mengatakan bahwa $\mathrm{z}$ baik dalam multitasking ataupun task switch meskipun perkembangan otak gen $Z$ ini juga memiliki efek buruk berupa AADD (acquired attention deficit disorder) yaitu perubahan pada otak karena pemakaian teknologi yang begitu besar oleh gen $Z$ yang berdampak kesulitan untuk fokus dan menganalisa informasi yang beragam, hal ini sangat dipengaruhi kebiasaan otak mendapatkan informasi yang pendek dan cepat melalui sosial media, Rothman (2014).

Gen Z di dunia kerja menurut Rothman (2014) akan berpindah - pindah kerja dengan cepat serta mampu menghasilkan dalam waktu singkat dibandingkan generasi sebelumnya. Generasi $Z$ akan memandang karir seperti beberapa hal : kebebasan, materialistis, global, eksperimental, teknologi tinggi, komitmen profesional. Generasi Z merepresentasikan perubahan generasi yang signifikan pada dunia kerja dan akan sangat penting untuk memahami darimana mereka datang serta memiliki strategi untuk menyambut mereka.

Generasi alpha merupakan anak - anak yang dilahirkan oleh generasi milenial. Istilah ini dikemukakan oleh mark Mc Crindle melalui tulisan di majalah Business Insider (Christina Sterbenz, 2015). Generasi alpha (2011 - 2025) generasi yang paling akrab dengan teknologi digital dan generasi yang diklaim paling cerdas dibandingkan generasi generasi sebelumnya. Sebanyak 2,5 juta anak generasi alpha lahir di dunia setiap minggunya. Gen A merupakan generasi paling akrab dengan internet sepanjang masa. Mc Crindler juga memprediksi bahwa generasi Alpha tidak lepas dari gadget, kurang bersosialisasi, kurang daya kreativitas dan bersikap individualis. Generasi alpha menginginkan hal-hal yang instan dan kurang menghargai proses. Keasyikan mereka dengan gadget membuat mereka teralienasi secara sosial.

Perkembangan anak (generasi alpha) di era 4.0. hal ini tentunya merubah cara pandang dan pola hidup masyarakat yang semula konvensional 


\begin{tabular}{|c|c|c|c|c|}
\hline $\begin{array}{c}\text { Focus: Jurnal } \\
\text { Pekerjaan Sosial }\end{array}$ & ISSN: $2620-3367$ & Vol. 2 No: 2 & Hal: $179-186$ & Desember 2019 \\
\hline
\end{tabular}

menjadi inkonvensional. Terlebih pertumbuhan teknologi, mau tidak mau masyarakat dituntut untuk berevolusi. Berdasarkan seluruh aspek kehidupan, peran keluarga yang paling penting dalam proses tumbuh kembang anak. Jika yang di bicarakan adalah generasi alpha, maka peran keluarga yang sudah pasti terdiri dari generasi $Y$ dan $Z$ yang cenderung sebagai pengambil keputusan, sementara generasi veteran dan $\mathrm{X}$ berperan sebagai konselor dan pendamping sehingga menghasilkan kolaborasi antar generasi menghasilkan new brainstorming terhadap generasi alpha.

Fenomena Anak belajar bagaimana menggunakan perangkat lunak (sudah mengenal touch screen) di usia dua tahun. Orang tua merasa panik dengan apa yang di bilan anaknya dan mendapatkan respon yang berbeda tidak sesuai dengan apa yang di bayangkan. Sebagai ayah juga harus memperhatikan dengan serius tentang kebiasaan anaknya bermain game pembunuhan dengan membunuh karakter yang ada didalam game. Cerita ini memberikan gambaran bagaimana anak sudah memasuki kedalam dunia yang berbeda di generasinya, tentu sangat tekjub dan memberikan permasalahan. Tetapi kejadian ini tidak dapat di hindari dikarenakan perkembangan zaman dan kemajuan teknologi yang semakin pesat. Hal ini membuat anak semakin lama dan sering di depan layar yang berdampak buruk untuk anak disisi lain aplikasi yang ada dapat membantu anak dalam mengasah keterampilan dan komunikasi. Hal ini di pengaruhi oleh teknologi dan budaya di generasi alfa, maka dapat dilihat denan tiga perspektif diantaranya : efek teknologi pada pikiran generasi alfa ; tren teknologi yang akan menunjukkan gambaran generasi alfa ; dan bagaimana mengorganisasikan dan memunculkan keunikan mampu mengarahkan generasi alfa. Inti dari semua ini tidak di peroleh dengan suatu prediksi, tetapi menggali, berdasarkan arus dan kegentingan trend, faktor inilah yang membuat generasi yang akan datang. Point penting untuk di ketahui bahwa batasan antar generasi sebagian besar bersifat arbitrasi dan jauh lebih banyak memiliki persamaan daripada perbedaan antara satu kelompok generasi dan generasi selanjutnya. Generasi alfa tidak lahir berbeda dengan milenial atau generasi $Z$, tetapi kepribadian, motivasi dan penampilan yang di tunjukkan akan mewarnai oleh mereka sebagai bagian yang tidak terpisahkan. Teknologi akan memberikan akses yang baik untuk mengarahkan pemikiran dan tindakan serta percepatan teknologi meningkatkan perubahan. Trend yang ditunjukan juga tidak dipengaruhi oleh generasi alfa, namun akan berdampak pada kondisi pertukaran mentalias antar generasi. Memahami perubahan tersebut akan memfokuskan peran dan perilaku.

Otak manusia dipengaruhi oleh stimulasi kata kata untuk berkembang. Tetapi beberapa dekade ini, anak memiliki kemampuan yang meningka dengan adanya teknologi digital untuk belajar, interaksi dan bermain. Hal ini meningkatkan kapasitas dalam pengetahuan dan intelegensi. Otak tidak dikembangkan dengan sendirinya ; ini dipengaruhi oleh pengalaman dengan lingkungan eksternal. Hal ini yang di sebut sebagai brain plasticity. Setiap keterampilan dan kemampuan yang kita punya diisi dengan bagaimana kita melakukan pendekatan dengan pikiran yang ada didunia" (Michael Merzenich, 2017 dalam understanding generation alpha). Seperti hal nya bagaimana teknologi mengubah pemikiran anak muda secara tidak langsung. Digaris bawahi sebagai pembeajaran : googel membuat menjadi bodoh ; smartphone membuat kita seperti zombie ; facebook membuat diri menjadi narsis kepada semua orang dan sebagainya. Pendapat tersebut tentang teknologi mengubah keterampilan yang dimiliki dimasa depan sepanjang dapat diikuti manusia dan aktifitas otak yang memberikan tugas yang monoton untuk selalu fokus dalam permasalahan yang memiliki permasalahan yang tinggi.

Generasi alfa sendiri akan memiliki suatu keterampilan yang di tunjukan (become more specialised) memiliki spesialisai. Merzenich melakukan observasi beberapa tahun ini menunjukkan meningkatnya spesialisasi. Serta memprediksi trend teknologi akan berlanjut di generasi alfa dan akan mendorong kearah auotomatisasi dengan memiliki kemampuan berdasarkan bidang spesialisasi untuk memenuhi tugas dalam bekerja. Automatisasi akan ada di bidang transportasi, manufaktur dan aktifitas yang memiliki resiko tinggi. (Michael Merzenich, 2017 dalam understanding generation alpha). Secara sederhana teknologi dapat membuat lebih pintar diantaranya (1) meningkatkan keterampilan visual (2) meningkatkan kemampuan kordinasi mata dan kemampuan dalam melakukan tugas (3) mengingkatkan skor dalam tugas (intelegensi test). Psikolog jean Twenge 2017 dalam understanding generastion alpha) menggambarkan berkembangnya smartphone dan sosial media dan meningkatnya depresi dan kesendirian di masa muda. Selain itu 


\begin{tabular}{|c|c|c|c|c|}
\hline $\begin{array}{c}\text { Focus: Jurnal } \\
\text { Pekerjaan Sosial }\end{array}$ & ISSN: $2620-3367$ & Vol. 2 No: 2 & Hal: $178-186$ & Desember 2019 \\
\hline
\end{tabular}

menemukan hasil dalam survey dan laporan menemukan igen kurang dalam berkegiatan, kurang minum dan jarang keluar rumah tetapi menghabiskan banyak waktunya untuk online. Twenge menghubungkan bahwa level kebahagiaan anak muda dengan waktunya dihabiskan lebih banyak di internet, social media dan pesan singkat seperti hal yang dilaporkan menjadi tidak bahagia. Secara tidak langsung generasi alpha menunjukkan teknologi baru akan membuat standar baku untuk generasi tersebut ; memiliki beragam pilihan, perbedaan dan jelas; video mendominasi media sosial dan generasi alpha akan memililki indentitas online ganda.

\section{SIMPULAN}

Perkembangan teknologi yang pesat tentunya mempengaruhi berbagai bidang yang ada seperti sosial yang berdampak kepada perkembangan interaksi sosial antar individu maupun masyarakat. Sehingga memunculkan generasi yang lebih modern dalam menghadapi era teknologi saat ini. Perkembangan anak (generasi alpha) di era 4.0. hal ini tentunya merubah cara pandang dan pola hidup masyarakat yang semula konvensional menjadi inkonvensional. Terlebih pertumbuhan teknologi, mau tidak mau masyarakat dituntut untuk berevolusi. Berdasarkan seluruh aspek kehidupan, peran keluarga yang paling penting dalam proses tumbuh kembang anak. Jika yang di bicarakan adalah generasi alpha, maka peran keluarga yang sudah pasti terdiri dari generasi $Y$ dan $Z$ yang cenderung sebagai pengambil keputusan, sementara generasi veteran dan $\mathrm{X}$ berperan sebagai konselor dan pendamping sehingga menghasilkan kolaborasi antar generasi menghasilkan new brainstorming terhadap generasi alpha. Mc Crindler juga memprediksi bahwa generasi Alpha tidak lepas dari gadget, kurang bersosialisasi, kurang daya kreativitas dan bersikap individualis. Generasi alpha menginginkan hal-hal yang instan dan kurang menghargai proses. Keasyikan mereka dengan gadget membuat mereka teralienasi secara sosial.

Pada sisi lain peran serta keluarga, terutama ayah dan ibu dalam memberikan pendidikan sangat penting. Apalagi, mengingat tantangan yang sangat besar mengacu pada 21st Century Partnership Learning Framework, bahwa pendidikan abad 21 harus mampu menghasilkan outcomes yang memiliki beberapa keterampilan utama, yaitu (1) learning and innovation skills yang mencakup : creativity and innovation, critical thinking and problem solving, communication and collaboration (2) information, media and technologi skills yang mencakup information literacy, media literacy and ICT (information, comunication and technology) literacy dan (3) life and career skills yang mencakup : flexibility and adaptability, initiative and self direction, social and cross cultural skills, productivity and accountability dan leadership and responsibility. Trend yang ditunjukan juga tidak dipengaruhi oleh generasi alfa, namun akan berdampak pada kondisi pertukaran mentalias antar generasi. Memahami perubahan tersebut akan memfokuskan peran dan perilaku.

Generasi alfa sendiri akan memiliki suatu keterampilan yang di tunjukan (become more specialised) memiliki spesialisai. Merzenich melakukan observasi beberapa tahun ini menunjukkan meningkatnya spesialisasi. Serta memprediksi trend teknologi akan berlanjut di generasi alfa dan akan mendorong kearah auotomatisasi.

Selain itu berkembangnya smartphone dan sosial media dan meningkatnya depresi dan kesendirian di masa muda. Selain itu menemukan hasil dalam survey dan laporan menemukan igen kurang dalam berkegiatan, kurang minum dan jarang keluar rumah tetapi menghabiskan banyak waktunya untuk online. Twenge menghubungkan bahwa level kebahagiaan anak muda dengan waktunya dihabiskan lebih banyak di internet, social media dan pesan singkat. Serta generasi alfa memiliki kemampuan ganda (multiple task), lebih spesialisasi (keterampilan) dan memiliki indentitas ganda yang menunjukkan citra diri yang tunjukkan di media sosial.

\section{DAFTAR PUSTAKA}

Christina Sterbenz. 2015. Here's who comes after Generation $Z$ and they'll be the most transformative age group ever. Business Insider.

Drath, R., \& Horch, A. (2014). Industrie 4.0: Hit or hype? [industry forum]. IEEE industrial electronics magazine, $8(2)$, pp. 56-58.

Davies, R. (2015). Industry 4.0 Digitalisation for productivity and growth. http://www.europarl.europa.eu/RegData/etu 


\begin{tabular}{|c|c|c|c|c|}
\hline $\begin{array}{c}\text { Focus: Jurnal } \\
\text { Pekerjaan Sosial }\end{array}$ & ISSN: $2620-3367$ & Vol. 2 No: 2 & Hal: $179-186$ & Desember 2019 \\
\hline
\end{tabular}

des/BRIE/2015/568337/EPRS_BRI(2015)568 337_EN.pdf.

Gunarsa, Singgih. (1989). Psikologi Perkembangan. Jakarta: PT. BPK Gunung Mulia.

Hurlock, E.B. (1980). Psikologi Perkembangan: Suatu Pendekatan Sepanjang Rentang Kehidupan. Edisi kelima. Jakarta: Erlangga.

Hurlock, E.B. 1993. Child Development, Mc Graw Hill Book Company, NY, USA, 1993, hal. 37.

Konakom, K., Saengchan, A., Kittisupakorn, P., and Mujtaba, I.M., 2010, High Purity Ethyl Acetate Production with a Batch Reactive Distillation Column using Dynamic Optimization Strategy, Proceedings of the World Congress on Engineering and Computer Science Vol II, San Francisco, USA.

Lankshear, C. \& Knobel, M. (ed). 2011. Literacies: Social, Cultural and Historical Perspectives. United States: Peter Lang Publishing Inc.

McCrindle, M. dan Wolfinger, E. 2010. Generations defined. Ethos, 18(1).

Moh. Nazir. Ph. D. 2005. Metode Penelitian. Bogor : Ghalia Indonesia.

Rothman, D. 2014. A Tsunami of Learners Called Generation $\quad Z$ (Online), (http://www.mdle.net/Journal/A_Tsunami_of _Learners_Called_Generation_Z.pdf, di-akses 5 Oktober 2016.

Santrock, J.W. (2002). Life-Span Development Perkembangan Masa Hidup jilid II. Edisi kelima. Jakarta: Erlangga.

Singh, A. (2014). Challenges and Issues of Generation Z, IOSR Journal of Business and Management (IOSR-JBM), 16 (7). 59-63.

Qin, J., Liu, Y., \& Grosvenor, R. (2016). A Categorical Framework of Manufacturing for Industry 4.0 and Beyond. Procedia CIRP, Vol. 52, pp. 173-178.
Victor Turk. 2017. Understanding Generation Alpha, Hotwire. UK.

http://id.priceprice.com/harga-hp/news/LaporanIDC-Pengiriman-Smartphone-di-IndonesiaMerosot-9-di-Q4-2017-dan-Samsung-MasihKuasai-Pasar-5305/

http://jambi.tribunnews.com/2017/01/08/ciri-ciridan-fakta-tentang-generasi-alpha-2.

http://www.p21.org/storage/documents/1._p21_fra mework_2-pager.pdf.

https://www.goodnewsfromindonesia.id/2018/02/06 /inilah-perkembangan-digitalindonesiatahun-2018. 